\title{
Enhancement of Hydrolysis through the Formation of Mixed Heterometal Species: $\mathrm{Al}^{3+} / \mathrm{CH}_{3} \mathrm{Sn}^{3+}$ Mixtures
}

\author{
Rosalia M. Cigala, ${ }^{\dagger}$ Concetta De Stefano, ${ }^{\dagger}$ Alba Giacalone, ${ }^{\ddagger}$ Antonio Gianguzza, ${ }^{\dagger}$ \\ and Silvio Sammartano*, ${ }^{\dagger}$ \\ ${ }^{\dagger}$ Dipartimento di Scienze Chimiche, Università di Messina, viale F. Stagno D’Alcontres, 31-98166 Messina, Italy \\ ${ }^{\ddagger}$ Dipartimento di Fisica e Chimica, Università di Palermo, viale delle Scienze, 90128 Palermo, Italy
}

ABSTRACT: The hydrolysis of mixed-metal cations $\left(\mathrm{Al}^{3+} / \mathrm{CH}_{3} \mathrm{Sn}^{3+}\right)$ was studied in aqueous solutions of $\mathrm{NaNO}_{3}$, at $I=1.00 \pm 0.05$ $\mathrm{mol} \cdot \mathrm{dm}^{-3}$ and $T=298.15 \mathrm{~K}$, by potentiometric technique. Several hydrolytic mixed species are formed in this mixed system, namely, $\mathrm{Al}_{p}\left(\mathrm{CH}_{3} \mathrm{Sn}\right)_{q}(\mathrm{OH})_{r}$ with $(p, q, r)=(1,1,4),(1,1,5),(1,1,6),(2,1$, $4),(1,2,5),(1,4,11),(1,3,8)$, and $(7,6,32)$. The stability of these species, expressed by the equilibrium: $p \mathrm{Al}^{3+}+q \mathrm{CH}_{3} \mathrm{Sn}^{3+}+r \mathrm{OH}^{-}=$ $\mathrm{Al}_{p}\left(\mathrm{CH}_{3} \mathrm{Sn}\right)_{q}(\mathrm{OH})_{r}^{3(p+q)-r}, \beta_{p q r}^{\mathrm{OH}}$, can be modeled by the empirical relationship: $\log \beta_{p q r}^{\mathrm{OH}}=-3.34+2.67 p+9.23(q+r)$. By using the equilibrium constant $X_{p q r}$ relative to the formation reaction: $p \mathrm{Al}_{(p+q)}(\mathrm{OH})_{r}+q\left(\mathrm{CH}_{3} \mathrm{Sn}\right)_{(p+q)}(\mathrm{OH})_{r}=(p+q) \mathrm{Al}_{p}\left(\mathrm{CH}_{3} \mathrm{Sn}\right)_{q}(\mathrm{OH})_{r}$, it was found that the formation of heterometal mixed species is thermodynamically favored, and the extra stability can be expressed as

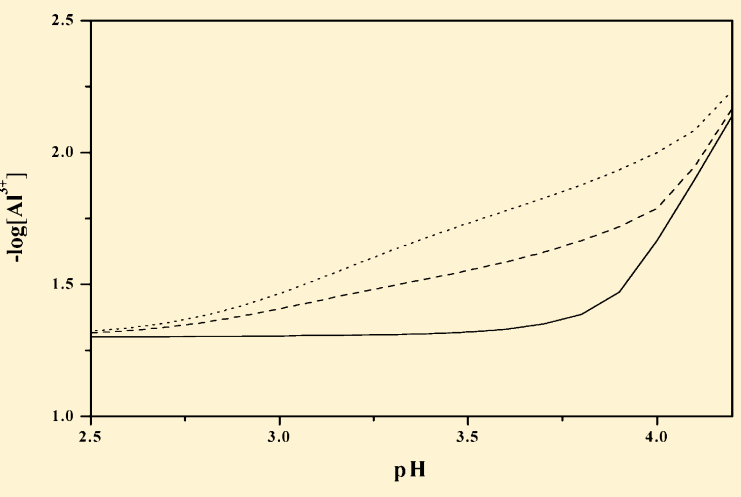
a function of the difference in the stability of parent homometal species. This leads, in turn, to a significant enhancement of hydrolysis and solubility.

\section{INTRODUCTION}

Natural waters and biologic fluids are multicomponent systems containing a variety of metal or organometal cations and ligands both inorganic and organic in nature. ${ }^{1-5}$ These components undergo complexation, forming several species; in many cases, in the presence of multicomponent mixtures (multimetal/ multiligand), one must take into consideration the possibility of mixed species formation, for example, one ligand with different metal cations (heterometal polynuclear complexes) or one metal with different ligands (mixed metal-ligand complexes). For a ternary system (one metal and two ligands or one ligand and two metals), the stability of the generic mixed complex $\mathrm{ABC}$ can be expressed, in addition to the overall formation constant $\beta_{111}=[\mathrm{ABC}] /([\mathrm{A}][\mathrm{B}][\mathrm{C}])$, by the constant $X$, relative to the equilibrium $\mathrm{AB}_{2}+\mathrm{AC}_{2}=2 \mathrm{ABC}$, whose statistical value $^{2,6}$ indicates that generally the stability for mixed complexes is higher than that of simple $A_{2}$ and $A_{2}$ species. Moreover, it has been shown that the extra stability is a function of the parameter $\Delta_{\text {parent }}$ (i.e., the difference in the stability of simple complexes). ${ }^{6}$

Mixed ligand complexes of several metal ions (in particular, transition metal cations) with small inorganic and organic ligands have been widely studied. ${ }^{7-9}$ In the old compilation of Perrin, ${ }^{8}$ dating back to 1979 , stability data relative to 1220 mixed ligand systems were reported. The literature data relative to the formation of mixed species containing one ligand and two metal ions are not very numerous, and in particular, few data are found when the ligand is $\mathrm{OH}^{-}$. From our research, it appeared that the most of studies were conducted by Russian and Belorussian scientists, using different techniques on several binary systems. The mixed hydrolysis of uranyl was analyzed with aluminum, while copper(II) was utilized for the investigation of ternary systems with $\mathrm{Cr}$ (III), $\mathrm{Co}(\mathrm{II}), \mathrm{Al}(\mathrm{III})$, $\mathrm{Sc}(\mathrm{III}), \mathrm{Fe}(\mathrm{III})$, and $\mathrm{Ni}(\mathrm{II}) .{ }^{10-20}$ The mixing effects on the protonation of some polyprotic acids, determined in electrolyte mixtures, were also interpreted in terms of mixed metal complexes. ${ }^{6,21-23}$

Yusov et al. ${ }^{20}$ reported a spectrophotometric study on the interaction of aluminum(III) with some $f$-family ions to form mixed hydroxo complexes. As an example, they found, for $\mathrm{PuO}_{2}{ }^{2+}$, the formation of the heterometal hydroxo species $\mathrm{PuO}_{2} \mathrm{Al}(\mathrm{OH})_{j}(j=2,3)$. Recently, our research group was involved in the study of heterometal polynuclear hydroxo species. $^{24,25}$ The interest for these species comes from a series of items. First of all, in the aquatic systems the major component is water itself, and as a consequence, all the metal cations undergo hydrolysis to some extent. ${ }^{26}$ With increasing the cation charge both the hydrolysis extent and the formation of polynuclear species increase. Therefore, in a mixture of metal cations having charges $z>1$, the possible formation of heteropolynuclear species is quite high.

This possibility has been recognized for some complexes of cations, namely, $\mathrm{UO}_{2}{ }^{2+}$ and $\mathrm{Cu}^{2+},\left(\mathrm{C}_{2} \mathrm{H}_{5}\right)_{2} \mathrm{Sn}^{2+}$, and $\mathrm{Cd}^{2+} \cdot 24,25$ For these three couples of cations, it was found that

Received: January 2, 2013

Accepted: February 20, 2013

Published: March 4, 2013 
heterometal hydrolytic species are formed and that there is enhancement of hydrolysis in mixed metal solutions. Note that, in turn, the hydrolysis enhancement by the formation of charged polynuclear species may imply an increasing effect for the solubility of metal hydroxides. This aspect is quite interesting for the speciation of aquatic systems.

As well-known, three-charged cations show a high tendency to form highly polynuclear hydrolytic species (e.g., $\left.\mathrm{Fe}_{12}(\mathrm{OH})_{34}{ }^{2+}, \mathrm{Al}_{13}(\mathrm{OH})_{32}{ }^{7+}\right),{ }^{27-29}$ and the possibility, in a mixture of trivalent cations, of mixed metal species formation can be easily predicted.

As part of a series of studies, ${ }^{24,25}$ an investigation on the hydrolysis behavior of mixtures of $\mathrm{Al}^{3+}$ and $\mathrm{CH}_{3} \mathrm{Sn}^{3+}$, in aqueous solutions of $\mathrm{NaNO}_{3}$, at $I=1.00 \pm 0.05 \mathrm{~mol} \cdot \mathrm{dm}^{-3}$ and $T=298.15 \mathrm{~K}$, is reported here.

\section{EXPERIMENTAL SECTION}

Chemicals. The aluminum(III) solutions were prepared and standardized as already reported in ref 28. Monomethyltin(IV) solutions were prepared by weighing trichloride salt (purchased by Aldrich), with a purity > $99 \%$, used without further purification.

Sodium nitrate (Aldrich) solutions, used as supporting electrolyte, were prepared by weighing the pure salt, dried in an oven at $T=383.15 \mathrm{~K}$ for at least $2 \mathrm{~h}$. Nitric acid and sodium hydroxide solutions were prepared by diluting concentrated ampules (Riedel-de Haën) and standardized with sodium carbonate (Aldrich) and potassium hydrogen phthalate, respectively. $\mathrm{NaOH}$ solutions were preserved from atmospheric $\mathrm{CO}_{2}$ by means of soda lime traps. Moreover, all reagents were of analytical grade, and the solutions were always prepared using $\mathrm{CO}_{2}$-free distilled water (conductivity $\leq 2 \mu \mathrm{S} \cdot \mathrm{cm}^{-1}$ ).

Procedure. The $\mathrm{Al}^{3+} / \mathrm{CH}_{3} \mathrm{Sn}^{3+}$ system was studied by potentiometric technique $\left(\mathrm{H}^{+}\right.$-glass electrode) in thermostatted cells at $T=298.15 \mathrm{~K}$. The measurements were carried out by titrating (with standard $\mathrm{CO}_{2}$-free sodium hydroxide) a volume of $25 \mathrm{~cm}^{3}$ solutions containing $\mathrm{CH}_{3} \mathrm{Sn}^{3+}$ [(40.0 to 90.0) $\left.\mathrm{mmol} \cdot \mathrm{dm}^{-3}\right], \mathrm{Al}^{3+}\left[(30.0\right.$ to 80.0$\left.) \mathrm{mmol} \cdot \mathrm{dm}^{-3}\right]$, and $\mathrm{NaNO}_{3}$ to adjust the ionic strength to desired value $\left(1.00 \mathrm{~mol} \cdot \mathrm{dm}^{-3}\right)$. The experimental conditions for potentiometric titrations are reported in Table 1. The titrations were carried out until precipitation (see below the section on the solubility of the system).

Table 1. Experimental Conditions for the Potentiometric Titrations ${ }^{a}$ of $\mathrm{Al}^{3+} / \mathrm{CH}_{3} \mathrm{Sn}^{3+}$ at $I=1.00 \pm 0.05 \mathrm{~mol} \cdot \mathrm{dm}^{-3}$ $\left(\mathrm{NaNO}_{3}\right)$ and $\mathrm{T}=298.15 \mathrm{~K}$

\begin{tabular}{cccc}
$\mathrm{CH}_{3} \mathrm{Sn}^{3+}$ & & & \\
\cline { 1 - 1 }$\cdot \mathrm{dm}^{-3}$ & $\mathrm{Al}^{3+}$ & tit. & readings \\
60.0 & 30.0 & 2 & 92 \\
80.1 & 40.0 & 2 & 100 \\
80.7 & 49.9 & 2 & 116 \\
60.2 & 50.0 & 2 & 101 \\
40.0 & 70.0 & 1 & 56 \\
89.9 & 60.0 & 2 & 115 \\
60.0 & 59.9 & 2 & 126 \\
90.0 & 80.0 & 2 & 125 \\
15.0 & 5.0 & 4 & 200 \\
total & & 19 & 1031
\end{tabular}

${ }^{a}$ With $\mathrm{NaOH} 1 \mathrm{~mol} \cdot \mathrm{dm}^{-3}$ (different standard solutions).
To minimize systematic errors and to check the repeatability of the measurements, the $\mathrm{Al}^{3+} / \mathrm{CH}_{3} \mathrm{Sn}^{3+}$ measurements were carried out by two operators, using two different experimental systems, as already described in refs 28 and 30.

All titrations were carried out at $T=298.15 \pm 0.1 \mathrm{~K}$, by using a thermo-cryostat HAAKE F3 digital, under magnetic stirring and bubbling purified presaturated $\mathrm{N}_{2}$ through the solution to exclude $\mathrm{O}_{2}$ and $\mathrm{CO}_{2}$ inside. To determine the formal glass electrode potential $\left(E^{\circ}\right)$ and the junction potential $\left(E_{\mathrm{j}}=\right.$ $j_{\mathrm{a}}\left[\mathrm{H}^{+}\right]$), independent titrations of acidic solutions (nitric acid) were performed with standard sodium hydroxide solutions in the same experimental conditions of ionic strength of the $\mathrm{Al}^{3+}$ / $\mathrm{CH}_{3} \mathrm{Sn}^{3+}$ measurements. The free proton concentration scale was used, that is, $\mathrm{pH} \equiv-\log \left[\mathrm{H}^{+}\right]$.

Calculations. The nonlinear least-squares computer program ESAB2 $\mathrm{M}^{31}$ was used to determine all parameters of the acid-base titrations: analytical reagent concentrations, electrode formal potential $E^{\circ}$, the coefficient $j_{\mathrm{a}}$ relative to acidic junction potential, $E_{\mathrm{j}}$, and the ionic product of water, $K_{\mathrm{w}}$. The hydrolysis constants of heterometal species were refined by the computer program BSTAC. ${ }^{32}$ The ES4ECI ${ }^{33}$ computer program was used to draw speciation diagrams and to compute the formation percentages of the species. Some calculations were also made using the computer program STACO $^{33}$ to check the proposed speciation model.

Hydrolysis constants are expressed according to the equilibria 1 to 3 :

$$
\begin{aligned}
& p \mathrm{Al}^{3+}+r \mathrm{H}_{2} \mathrm{O}=\mathrm{Al}_{p}(\mathrm{OH})_{r}^{(3 p-r)}+r \mathrm{H}^{+} \beta_{p 0 r} \\
& q \mathrm{CH}_{3} \mathrm{Sn}^{3+}+r \mathrm{H}_{2} \mathrm{O}=\left(\mathrm{CH}_{3} \mathrm{Sn}\right)_{q}(\mathrm{OH})_{r}^{(3 q-r)}+r \mathrm{H}^{+} \\
& p \beta_{0 q r}{ }^{3+}+q \mathrm{CH}_{3} \mathrm{Sn}^{3+}+r \mathrm{H}_{2} \mathrm{O} \\
& \quad=\mathrm{Al}_{p}\left(\mathrm{CH}_{3} \mathrm{Sn}\right)_{q}(\mathrm{OH})_{r}^{(3(p+q)-r)}+r \mathrm{H}^{+} \quad \beta_{p q r}
\end{aligned}
$$

and formation constants are given by the equilibria 4 to 6 :

$$
\begin{aligned}
& p \mathrm{Al}^{3+}+r \mathrm{OH}^{-}=\mathrm{Al}_{p}(\mathrm{OH})_{r}^{(3 p-r)} \quad \beta_{p 0 r}^{\mathrm{OH}} \\
& q \mathrm{CH}_{3} \mathrm{Sn}^{3+}+r \mathrm{OH}^{-}=\left(\mathrm{CH}_{3} \mathrm{Sn}\right)_{q}(\mathrm{OH})_{r}^{(3 q-r)} \quad \beta_{0 q r}^{\mathrm{OH}} \\
& p \mathrm{Al}^{3+}+q \mathrm{CH}_{3} \mathrm{Sn}^{3+}+r \mathrm{OH}^{-} \\
& =\mathrm{Al}_{p}\left(\mathrm{CH}_{3} \mathrm{Sn}\right)_{q}(\mathrm{OH})_{r}{ }^{(3(p+q)-r)} \quad \beta_{p q r}^{\mathrm{OH}}
\end{aligned}
$$

The conversion from molar to molal concentration scale can be obtained using the equation: $c / m=d+a_{1} \cdot c+a_{2} \cdot c^{2}$ (at $T=$ $298.15 \mathrm{~K}, d=$ solvent density $=0.9971 \mathrm{~g} \cdot \mathrm{cm}^{-3} ; c=$ molar concentration; $m=$ molal concentration; $a_{1}=0.02983151, a_{2}=$ $-6.4516 \cdot 10^{-4}$ in $\left.\mathrm{NaNO}_{3}\right)$. In the case of $1 \mathrm{~mol} \cdot \mathrm{dm}^{-3} \mathrm{NaNO}_{3}$, $I($ molal $)=1.03$ and $\log \beta($ molal $)=\log \beta$ (molar $)-0.015 \cdot p^{*}$ $\left[p^{*}=p-r-1\right.$, for equilibria 1 to 3 or $p^{*}=p+r-1$, for equilibria 4 to 6$]$.

\section{RESULTS AND DISCUSSION}

Hydrolysis of $\mathrm{Al}^{3+}$ and $\mathrm{CH}_{3} \mathrm{Sn}^{3+}$. The hydrolysis of $\mathrm{Al}^{3+}$ and $\mathrm{CH}_{3} \mathrm{Sn}^{3+}$ was already studied in these laboratories, ${ }^{28,30}$ and the constants relative to the equilibria 1 and 2 are reported in Table 2. These hydrolysis constants were determined in rather high metal concentration conditions, ${ }^{28,30}$ to find the formation of high homopolynuclear species, that means, for mixed metal 
Table 2. Equilibrium Constants for the Formation of Hydrolytic Species of $\mathrm{Al}^{3+}$ and $\mathrm{CH}_{3} \mathrm{Sn}^{3+}$, at $\mathrm{I}=1.00 \pm 0.05 \mathrm{~mol} \cdot \mathrm{dm}^{-3}$ $\left(\mathrm{NaNO}_{3}\right)$ and $\mathrm{T}=298.15 \mathrm{~K}$

\begin{tabular}{|c|c|c|c|c|c|c|c|c|c|}
\hline$p$ & $r$ & $\mathrm{Al}^{3+a}$ & $\log \beta_{p 0 r}^{b}$ & $\log \beta_{p 0 r}^{\mathrm{OH} c}$ & $q$ & $r$ & $\mathrm{CH}_{3} \mathrm{Sn}^{3+d}$ & $\log \beta_{0 q r}{ }^{e}$ & $\log \beta_{0 p r}^{\mathrm{OH} f}$ \\
\hline 1 & 1 & & -5.01 & 8.73 & 1 & 3 & & -9.91 & 31.28 \\
\hline 1 & 2 & & -10.5 & 17.0 & 1 & 4 & & -22.52 & 32.4 \\
\hline 1 & 3 & & -16.2 & 25.0 & 2 & 4 & & -3.81 & 51.11 \\
\hline 1 & 4 & & -23.4 & 31.5 & 2 & 5 & & -8.10 & 60.55 \\
\hline 3 & 4 & & -13.71 & 41.24 & 2 & 7 & & -30.65 & 65.46 \\
\hline \multirow[t]{4}{*}{13} & 32 & & -109.13 & 330.53 & 3 & 5 & & -1.89 & 66.76 \\
\hline & & & & & 3 & 7 & & -8.23 & 87.88 \\
\hline & & & & & 5 & 9 & & -2.73 & 120.84 \\
\hline & & & & & 5 & 11 & & -9.16 & 141.87 \\
\hline
\end{tabular}

${ }^{a}$ Reference 28. ${ }^{b} \log \beta_{p 0 r}$ refers to equilibrium $1 .{ }^{c} \log \beta_{p 0 r}^{\mathrm{OH}}$ refers to equilibrium $4 .{ }^{d}$ Reference $30 .{ }^{c} \log \beta_{0 q r}$ refers to equilibrium $2 .{ }^{f} \log \beta_{0 p r}^{\mathrm{OH}}$ refers to equilibrium 5 .

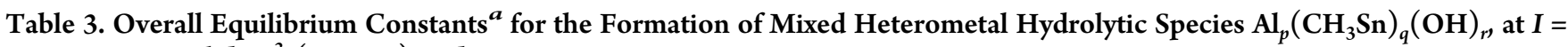
$1.00 \pm 0.05 \mathrm{~mol} \cdot \mathrm{dm}^{-3}\left(\mathrm{NaNO}_{3}\right)$ and $T=298.15 \mathrm{~K}$

\begin{tabular}{|c|c|c|c|c|c|c|}
\hline$p$ & $q$ & $r$ & model 1 & model 2 & model 3 & model 4 \\
\hline 1 & 1 & 4 & $-8.91(8)^{b}$ & & & $-8.88(4)^{b}$ \\
\hline 1 & 1 & 5 & $-12.58(1)$ & $-12.532(6)^{b}$ & $-12.77(2)^{b}$ & $-12.80(2)$ \\
\hline 1 & 1 & 6 & $-19.45(5)$ & $-19.74(7)$ & $-19.53(4)$ & $-19.48(4)$ \\
\hline 2 & 1 & 4 & $-6.35(1)$ & $-6.66(2)$ & $-6.71(1)$ & $-6.79(2)$ \\
\hline 1 & 2 & 5 & $-4.83(2)$ & $-5.65(9)$ & $-6.04(20)$ & $-5.61(8)$ \\
\hline 1 & 4 & 11 & $-13.01(2)$ & $-13.30(2)$ & $-13.17(2)$ & $-13.22(2)$ \\
\hline 10 & 3 & 32 & $-91.44(19)$ & $-91.56(18)$ & & \\
\hline 1 & 3 & 8 & & $-8.599(9)$ & $-8.619(9)$ & $-8.67(1)$ \\
\hline 7 & 6 & 32 & & & $-73.23(3)$ & $-73.14(5)$ \\
\hline$\sigma^{2} / \sigma_{0}^{2}$ & & & 1.45 & 1.28 & 1.15 & 1.00 \\
\hline
\end{tabular}

${ }^{a}$ According to equilibrium $3 .{ }^{b}$ Least-squares standard deviation in parentheses.

solutions, high probability for the formation of heterometal hydrolytic species. Aluminum(III) forms, in addition to the mononuclear species, two polynuclear hydrolysis products, and monomethyltin(IV) cation undergoes hydrolysis mainly in terms of several polynuclear species. The hydrolysis trend is $\mathrm{CH}_{3} \mathrm{Sn}^{3+} \gg \mathrm{Al}^{3+}$.

As already recognized by Brown et al., ${ }^{27}$ in some cases the hydrolysis constants $\beta$ (or the formation constants $\beta^{\mathrm{OH}}$ ) can be expressed by a single equation as a function of stoichiometric coefficients. By considering equilibrium 4, least-squares calculations give, for $\mathrm{Al}^{3+}:{ }^{28}$

$$
\log \beta_{p 0 r}^{\mathrm{OH}}=-4.78+3.32 p+9.12 r
$$

and for $\mathrm{CH}_{3} \mathrm{Sn}^{3+30}$ equilibrium 5:

$$
\log \beta_{0 q r}^{\mathrm{OH}}=8.50(q+r)
$$

the errors associated with $\log \beta^{\mathrm{OH}}$ calculated by eq 7 and 8 are, as a mean, $\pm 0.5 \log$ units, i.e., compatible with predicting purposes.

Formation of Heterometal Hydrolytic Species. Leastsquares analysis of potentiometric data was performed by considering a variety of $p, q$, and $r$ stoichiometric coefficients, according to equilibria 3 or 6 .

In Table 3, the results relative to four tested models (the most significant models) are collected. Model 4 was chosen on the basis of the best variance ratio. Eight species are taken into consideration, and their standard deviations are always very good, by taking into account the complexity of the mixed metal system. Hydrolysis constants were converted to formation constants using the equation:

$$
\log \beta_{p q r}^{\mathrm{OH}}=\log \beta_{p q r}+13.73 r
$$

and the relative values are reported in Table 4. A preliminary analysis of these data indicates that $\log \beta_{p q r}^{\mathrm{OH}}$ is a function of the stoichiometric coefficients, as observed for homometal hydro-

Table 4. Overall Equilibrium Constants for the Formation of Heterometal Hydrolytic Species Together with Equilibrium

\begin{tabular}{|c|c|c|c|c|c|c|}
\hline$p$ & $q$ & $r$ & $\log \beta_{p q r}^{\mathrm{OH}}$ & $\log \beta_{p 0 r}^{\mathrm{OH}}$ & $\log \beta_{0 p r}^{\mathrm{OH}}$ & $\log X$ \\
\hline \multirow[t]{2}{*}{1} & 1 & 4 & $46.04 \pm 0.12^{a, b}$ & & $51.1^{b}$ & $2.6 \pm 0.4^{a, c}$ \\
\hline & & & $45.5 \pm 0.2$ & $38.34^{b}$ & & 0.6 \\
\hline \multirow[t]{2}{*}{1} & 1 & 5 & $55.85 \pm 0.12$ & & 60.5 & $3.7 \pm 0.3$ \\
\hline & & & $54.7 \pm 0.2$ & 47.46 & & 0.6 \\
\hline \multirow[t]{2}{*}{1} & 1 & 6 & $62.9 \pm 0.15$ & & & $1.2 \pm 1.2$ \\
\hline & & & $63.9 \pm 0.2$ & 56.58 & 68.0 & 0.6 \\
\hline \multirow[t]{2}{*}{2} & 1 & 4 & $48.13 \pm 0.1$ & 41.24 & & $2.4 \pm 0.5$ \\
\hline & & & $48.1 \pm 0.2$ & & 59.5 & 1.4 \\
\hline \multirow[t]{2}{*}{1} & 2 & 5 & $63.04 \pm 0.15$ & & 66.8 & $4.8 \pm 0.6$ \\
\hline & & & $63.9 \pm 0.4$ & 50.78 & & 1.4 \\
\hline \multirow[t]{2}{*}{1} & 4 & 11 & $137.8 \pm 0.2$ & & 147.9 & $9.5 \pm 1.0$ \\
\hline & & & $137.8 \pm 0.5$ & 112.14 & & 3.5 \\
\hline \multirow[t]{2}{*}{1} & 3 & 8 & $101.2 \pm 0.2$ & & & $17.2 \pm 4.3$ \\
\hline & & & $100.9 \pm 0.3$ & 81.46 & 102.0 & 2.4 \\
\hline \multirow[t]{2}{*}{7} & 6 & 32 & $366.2 \pm 0.7$ & 330.53 & & $152 \pm 12$ \\
\hline & & & $366.1 \pm 1.3$ & & 382.5 & 42 \\
\hline
\end{tabular}
Constants for Parent Homonuclear Complexes, at $I=1.00 \pm$ $0.05 \mathrm{~mol} \cdot \mathrm{dm}^{-3}\left(\mathrm{NaNO}_{3}\right)$ and $T=298.15 \mathrm{~K}$

${ }^{a} \pm 95 \%$ C.I.. ${ }^{b}$ First row: experimental values; second row: calculated values. ${ }^{c}$ First row: experimental values; second row: statistical values $\left(\log X_{\text {stat }}\right)$. 
lytic species of both $\mathrm{Al}^{3+}$ and $\mathrm{CH}_{3} \mathrm{Sn}^{3+}$. By least-squares analysis the following relationship was obtained:

$$
\log \beta_{p q r}^{\mathrm{OH}}=-3.34+2.67 p+9.23(q+r)
$$

This equation fits quite well experimental data, with a correlation coefficient $r=0.999$ for the straight line log $\beta_{p q r}^{\mathrm{OH}}$ (calcd) vs. $\log \beta_{p q r}^{\mathrm{OH}}(\exp )$, and a predicted error of calculated values is given by the equation (also in this case function of stoichiometric coefficients):

$$
\varepsilon=0.028(p+q+r)
$$

( $\varepsilon=95 \%$ confidence interval).

The yield of mixed species is quite significant, in particular in the acidic $\mathrm{pH}$ range, as shown in Figure 1, where the fraction of

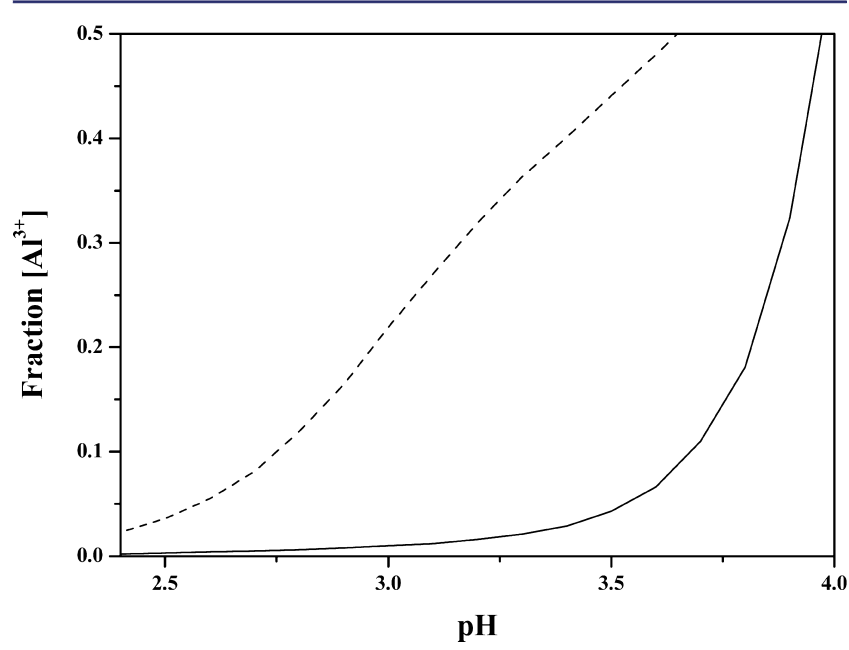

Figure 1. Speciation diagram of $\mathrm{Al}^{3+} / \mathrm{CH}_{3} \mathrm{Sn}^{3+} / \mathrm{OH}^{-}$system vs. $\mathrm{pH}$. Full line: sum of the $\mathrm{Al}_{p}(\mathrm{OH})_{r}$ simple hydrolytic species; Dashed line: sum of $\mathrm{Al}_{p}\left(\mathrm{CH}_{3} \mathrm{Sn}\right)_{q}(\mathrm{OH})_{r}$ mixed heterometal hydrolytic species. Experimental conditions: $\left[\mathrm{Al}^{3+}\right]_{\mathrm{T}}=50.0 \mathrm{mmol} \cdot \mathrm{dm}^{-3},\left[\mathrm{CH}_{3} \mathrm{Sn}^{3+}\right]_{\mathrm{T}}=$ $50.0 \mathrm{mmol} \cdot \mathrm{dm}^{-3}$; at $I=1.00 \pm 0.05 \mathrm{~mol} \cdot \mathrm{dm}^{-3}\left(\mathrm{NaNO}_{3}\right)$ and $T=$ $298.15 \mathrm{~K}$.

$\mathrm{Al}^{3+}$ present as mixed species $\left(x_{\mathrm{T}}=\Sigma\left([\right.\right.$ mixed species $\left.] /\left[\mathrm{Al}^{3+}\right]_{\mathrm{T}}\right)$ is reported vs $\mathrm{pH}$, when the concentration of both cations is $50.0 \mathrm{mmol} \cdot \mathrm{dm}^{-3}$. In these conditions at $\mathrm{pH}=3.0, x_{\mathrm{T}} \sim 0.2$ and at $\mathrm{pH}=3.8, x_{\mathrm{T}} \sim 0.5$.The speciation diagram is plotted in Figure 2 in the concentration conditions $\left[\mathrm{Al}^{3+}\right]=30.0$ $\mathrm{mmol} \cdot \mathrm{dm}^{-3}$ and $\left[\mathrm{CH}_{3} \mathrm{Sn}^{3+}\right]=60.0 \mathrm{mmol} \cdot \mathrm{dm}^{-3}$. In all the considered $\mathrm{pH}$ range highly mixed polynuclear species are formed, for example, $(1,3,8),(1,4,11)$, and $(7,6,32)$. Some species considered in the speciation model (Table 3 ) like $(1,1, r), r=4,5,6$ are formed at $\mathrm{pH}>4$, and for $r=6$ very low yields are observed.

The stability of mixed complexes can be evidenced by considering the equilibrium:

$$
\begin{aligned}
& p \mathrm{Al}_{(p+q)}(\mathrm{OH})_{r}^{(3(p+q)-r)}+q\left(\mathrm{CH}_{3} \mathrm{Sn}\right)_{(p+q)}(\mathrm{OH})_{r}^{(3(p+q)-r)} \\
& =(p+q) \mathrm{Al}_{p}\left(\mathrm{CH}_{3} \mathrm{Sn}\right)_{q}(\mathrm{OH})_{r}^{(3(p+q)-r)}
\end{aligned}
$$

with the equilibrium constant $X,{ }^{24,25}$ given by:

$$
\log X=(p+q) \log \beta_{p q r}^{\mathrm{OH}}-p \log \beta_{(p+q) 0 r}^{\mathrm{OH}}-q \log \beta_{0(p+q) r}^{\mathrm{OH}}
$$

The statistical values of $X$ can be calculated according to the equation: ${ }^{2}$

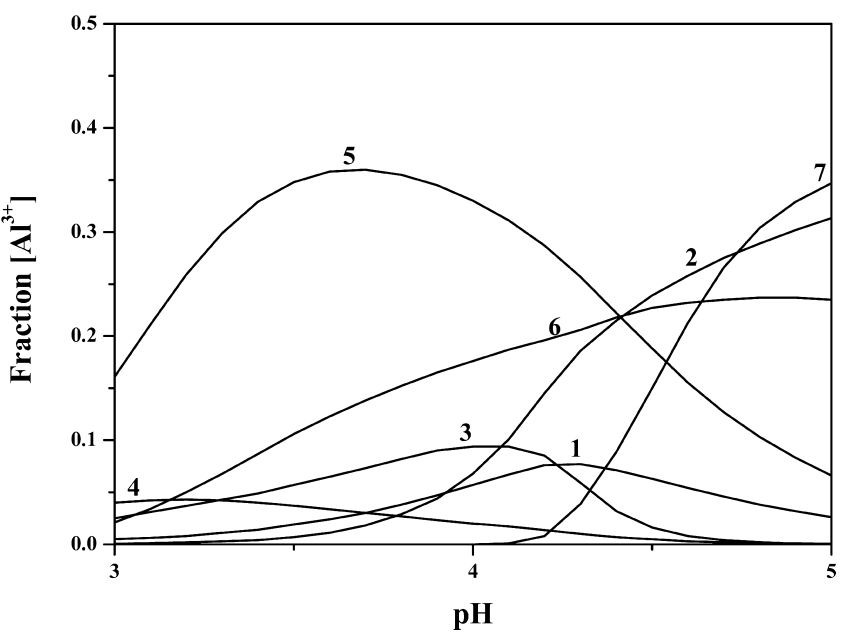

Figure 2. Speciation diagram of mixed heterocations hydrolytic species $\mathrm{Al}_{p}\left(\mathrm{CH}_{3} \mathrm{Sn}\right)_{q}(\mathrm{OH})_{r}$. Experimental conditions: $\left[\mathrm{Al}^{3+}\right]_{\mathrm{T}}=30.0$ $\mathrm{mmol} \cdot \mathrm{dm}^{-3},\left[\mathrm{CH}_{3} \mathrm{Sn}^{3+}\right]_{\mathrm{T}}=60.0 \mathrm{mmol} \cdot \mathrm{dm}^{-3}$, at $I=1.00 \pm 0.05$ $\mathrm{mol} \cdot \mathrm{dm}^{-3}\left(\mathrm{NaNO}_{3}\right)$ and $\mathrm{T}=298.15 \mathrm{~K}$. Species: $1 \mathrm{Al}\left(\mathrm{CH}_{3} \mathrm{Sn}\right)(\mathrm{OH})_{4}$, $2 \mathrm{Al}\left(\mathrm{CH}_{3} \mathrm{Sn}\right)(\mathrm{OH})_{5}, 3 \mathrm{Al}_{2}\left(\mathrm{CH}_{3} \mathrm{Sn}\right)(\mathrm{OH})_{4}, 4 \mathrm{Al}\left(\mathrm{CH}_{3} \mathrm{Sn}\right)_{2}(\mathrm{OH})_{5}, 5$ $\mathrm{Al}\left(\mathrm{CH}_{3} \mathrm{Sn}\right)_{3}(\mathrm{OH})_{8}, 6 \mathrm{Al}\left(\mathrm{CH}_{3} \mathrm{Sn}\right)_{4}(\mathrm{OH})_{11}, 7 \mathrm{Al}_{7}\left(\mathrm{CH}_{3} \mathrm{Sn}\right)_{6}(\mathrm{OH})_{32}$ (charges omitted).

$$
X_{\text {stat }}=[(p+q) ! /(p ! q !)]^{(p+q)}
$$

In Table $4, \log X$ and $\log X_{\text {stat }}$ values together with $\log \beta^{\mathrm{OH}}$ for parent homometal species are reported. For some (parent) species, not experimentally accessible, the relative equilibrium constants were calculated by the empirical eqs 7 and 8 .

Extra Stability of Heterometal Hydrolytic Species. Equation 14 for the statistical values of $X$ indicates that the formation of mixed species must be always favored, since $(p+$ $q) !>(p ! q !)$. Moreover, in many cases it was observed, for both mixed metal and mixed ligand complexes, an enhancement of the stability higher than that expected on the basis of statistical considerations, that is, $\log X$ (experimental) $>\log X_{\text {stat }}$. Also for the equilibrium constant 12 , a simple empirical relationship (15), as a function of the stoichiometric coefficients, was found:

$$
\begin{aligned}
& \log X=\Delta_{\text {parent }}-3(4 p+q)+4.85 p \cdot q \\
& \left(\Delta_{\text {parent }}=\mid \log \beta_{(p+q) 0 r}-\log \beta_{0(p+q) r}\right)
\end{aligned}
$$

The comparison of eqs 14 and 15 and the analysis of the differences $\log X-\log X_{\text {stat }}$ (Table 4), shows that for the mixed species $\mathrm{Al}_{p}\left(\mathrm{CH}_{3} \mathrm{Sn}\right)_{q}(\mathrm{OH})_{r}$ there is a strong extra stabilization.

This extra stability, that we indicate in this paper with $\Delta_{\text {extra }}$ $\left(\log X-\log X_{\text {stat }}\right)$, for simple $(11 r)$ species is $\Delta_{\text {extra }}=2 \pm 1 \log$ units, while for highly polynuclear species an extra stability of several orders of magnitude was calculated.

It has been observed that the statistical value calculated by eq 14 is valid only if the stability of parent complexes is similar (same order of magnitude), ${ }^{2}$ namely, $\log \beta_{(p+q) 0 r}^{\mathrm{OH}} \sim \beta_{(p+q) 0 r^{\prime}}^{\mathrm{OH}}$ while when they are quite different $X_{\text {stat }}$ may assume much higher values.

By investigating the formation of mixed metal (alkali and alkaline earth) complexes of diethylenetriaminepentaacetate and triethylenetetraaminehexaacetate, ${ }^{6}$ it was observed a linear dependence of $\Delta_{\text {extra }}$ on the stability difference of parent complexes, and by analyzing some previous data, ${ }^{34}$ the simple relationship (16) was found. 


$$
\Delta_{\text {extra }}=0.19 \Delta_{\text {parent }}
$$

The same considerations, applied to the data of the $\mathrm{Al}^{3+}$ / $\mathrm{CH}_{3} \mathrm{Sn}^{3+} / \mathrm{OH}^{-}$system, allow to obtain a very similar equation:

$$
\Delta_{\text {extra }}=0.22 \Delta_{\text {parent }}
$$

valid for all the species but the $(7,6,32)$ one.

Reliability of the Proposed Speciation Model and Errors in the Different Equilibrium Constants. The procedure of model selection followed in this investigation is very similar to that reported in our previous papers and in the literature. ${ }^{35}$ Model 4 was selected on the basis of variance ratio, as reported in Table 3. In this table it can be noted that model 3 is not very different, in terms of both speciation and variance ratio, but model 4 was chosen since the species $(1,1,4)$ is able to fit in a better way the first part of titrations, at $\mathrm{pH}<4$. Moreover, standard deviations on the hydrolysis constants are quite acceptable for all the species considered. Standard deviation on $\log \beta^{\mathrm{OH}}$ values for homometal species were calculated by eq 11 .

A source of errors may arise from the variation of ionic strength in the titrations of solutions containing high concentrations of trivalent cations. Nevertheless, for the most important parameter which characterize the formation of the mixed species, that is, $\log X$, the error due to the variation on ionic strength must be quite low, being the sum of the square charges equal in the two sides of equilibrium 12.

Enhancement of Hydrolysis. The most interesting consequence of the formation of mixed hydrolytic species, with high extra stability, is the enhancement of hydrolysis and the corresponding lowering of free metal concentration, as shown in Figure 3, where the free $\mathrm{Al}^{3+}$ concentration is reported vs. $\mathrm{pH}$ at different total concentrations and concentration ratios of the two cations considered.

The solubility of $\mathrm{Al}^{3+}$ is expressed by the equation:

$$
S_{\mathrm{Al}}=\left[\mathrm{Al}^{3+}\right]+\sum p\left[\mathrm{Al}_{p}(\mathrm{OH})_{r}^{(3 p-r)}\right]
$$

or

$$
S_{\mathrm{Al}}=K_{S 0}^{*}\left[\mathrm{H}^{+}\right]^{3}+\sum p \beta_{p r}\left(K_{S 0}^{*}\left[\mathrm{H}^{+}\right]^{3}\right)^{p}\left[\mathrm{H}^{+}\right]^{-r}
$$

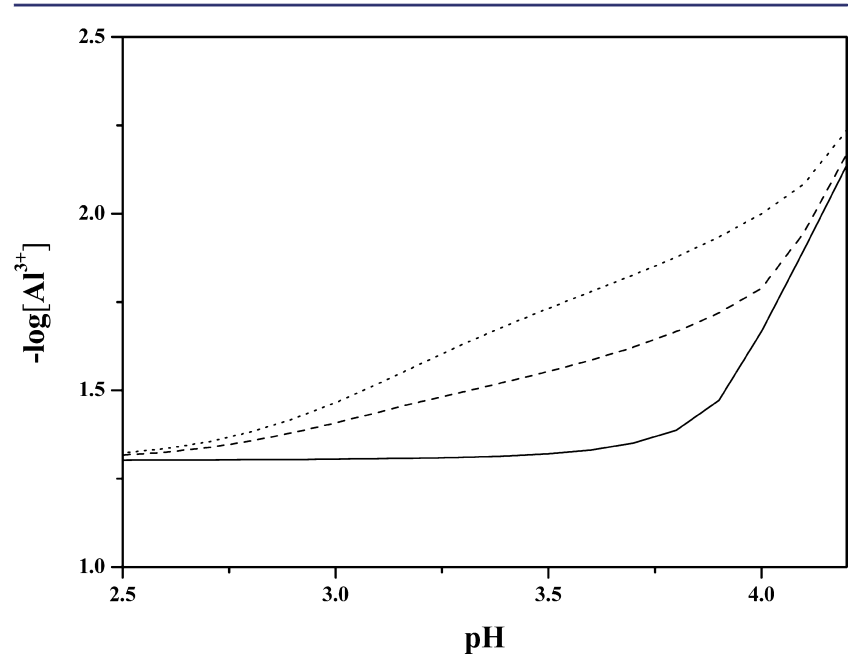

Figure 3. Plot of $-\log \left[\mathrm{Al}^{3+}\right]$ vs $\mathrm{pH}$ at different $\left[\mathrm{CH}_{3} \mathrm{Sn}^{3+}\right]_{\mathrm{T}}$ concentrations, when $\left[\mathrm{Al}^{3+}\right]_{\mathrm{T}}=50 \mathrm{mmol} \cdot \mathrm{dm}^{-3} ;\left[\mathrm{CH}_{3} \mathrm{Sn}^{3+}\right]_{\mathrm{T}}=0$, full line; $\left[\mathrm{CH}_{3} \mathrm{Sn}^{3+}\right]_{\mathrm{T}}=50 \mathrm{mmol} \cdot \mathrm{dm}^{-3}$, dashed line; $\left[\mathrm{CH}_{3} \mathrm{Sn}^{3+}\right]_{\mathrm{T}}=100$ $\mathrm{mmol} \cdot \mathrm{dm}^{-3}$, dotted line. where $K_{S 0}^{*}=\left[\mathrm{Al}^{3+}\right] /\left[\mathrm{H}^{+}\right]^{3}=9.2$ at $I=1.00 \pm 0.05 \mathrm{~mol} \cdot \mathrm{dm}^{-3}$ $\left(\mathrm{NaNO}_{3}\right)$ and $\mathrm{T}=298.15 \mathrm{~K}$.

When another cationic species, such as $\mathrm{CH}_{3} \mathrm{Sn}^{3+}$, forms mixed species together with aluminum cation, a further term, $S_{\text {mix }}$ must be added to eq 18 :

$$
S_{\text {mix }}=\sum p\left[\mathrm{Al}_{p}\left(\mathrm{CH}_{3} \mathrm{Sn}\right)_{q}(\mathrm{OH})_{r}^{(3(p+q)-r)}\right]
$$

or

$$
S_{\text {mix }}=\sum p \beta_{p q r}\left(K_{S 0}^{*}\left[\mathrm{H}^{+}\right]^{3}\right)^{p}\left[\mathrm{CH}_{3} \mathrm{Sn}^{3+}\right]^{q}\left[\mathrm{H}^{+}\right]^{-r}
$$

The term (21) is always $>0$, and therefore, the solubility increases as a function of both the value of $\beta_{p q r}$ and the concentration of the monomethyltin(IV) cation.

Using the values of $K_{S 0}$ and $\beta_{p q r}$ for the various mixed species, the $\mathrm{pH}$ value for the formation of insoluble $\mathrm{Al}(\mathrm{OH})_{3(\mathrm{~s})}$ species was calculated:

$$
\begin{aligned}
\mathrm{pH}_{(\text {solubility) }}( \pm 0.1)= & 3.08-1.2 \log \left[\mathrm{Al}^{3+}\right]_{\mathrm{T}} \\
& +0.92 \log \left[\mathrm{CH}_{3} \mathrm{Sn}^{3+}\right]_{\mathrm{T}}
\end{aligned}
$$

while in the absence of $\mathrm{CH}_{3} \mathrm{Sn}^{3+}$ :

$$
\mathrm{pH}_{(\text {solubility })}( \pm 0.1)=3.08-0.34 \log \left[\mathrm{Al}^{3+}\right]_{\mathrm{T}}
$$

where []$_{\mathrm{T}}$ indicates the total concentrations. Therefore the difference in $\mathrm{pH}_{(\text {solubility })}$ is:

$$
\begin{aligned}
\Delta \mathrm{pH}_{(\text {solubility })}( \pm 0.15)= & -0.86 \log \left[\mathrm{Al}^{3+}\right]_{\mathrm{T}} \\
& +0.92 \log \left[\mathrm{CH}_{3} \mathrm{Sn}^{3+}\right]_{\mathrm{T}}
\end{aligned}
$$

that quantitatively accounts for the increasing effect of the presence of $\mathrm{CH}_{3} \mathrm{Sn}^{3+}$ on the solubility. Equations 22 and 23 are valid in the concentration range $1<-\log \left[\mathrm{M}^{3+}\right]_{\mathrm{T}}<3$.

\section{FINAL REMARKS}

In aqueous solution containing $\mathrm{Al}^{3+}$ and $\mathrm{CH}_{3} \mathrm{Sn}^{3+}$ several mixed cation hydrolytic species are formed. The main results obtained in this work can be summarized as follows:

- The mixed hydrolysis products show a remarkable stability, and in particular in acidic solutions, stability is present in a large number of polynuclear species.

- The mixed species exhibit a strong extra stability higher than that expected based on pure statistics.

- The high polynuclearity of many mixed species indicates that, in fairly high concentration conditions, many of these species can be formed for pairs of trivalent cations.

- The formation of mixed species implies, as reported previously, an increase of hydrolysis and therefore of the solubility of the whole mixed system.

- Finally, as observed for many systems, it is possible to draw from the experimental data some empirical relationships that can be useful for prediction, probably also for other similar systems.

\section{AUTHOR INFORMATION}

\section{Corresponding Author}

*E-mail: ssammartano@unime.it.

\section{Funding}

We thank the Universities of Messina and Palermo for partial financial support. 


\section{Notes}

The authors declare no competing financial interest.

\section{REFERENCES}

(1) Buffle, J. Complexation Reactions in Aquatic Systems: An Analytical Approach; Ellis Horwood Ltd.: Chichester, U.K., 1988.

(2) Grenthe, I.; Puigdomenech, I.; Allard, B. Modelling in Aquatic Chemistry; Paris: Nuclear Energy Agency, OECD: Washington, DC, 1997.

(3) Lentner, C. Physical Chemistry. Composition of the Blood. Haematology. Human Somatometric Data; Ciba Geigy: Basel, 1984.

(4) Millero, F. J. Chemical Oceanography; CRC Press: Boca Raton, FL, 1996.

(5) Millero, F. J. Sea Water as an Electrolyte. In Chemistry of Marine Waters and Sediments; Gianguzza, A., Pelizzetti, E., Sammartano, S., Eds.; Springer: Berlin, 2002; pp 3-32.

(6) De Stefano, C.; Sammartano, S.; Gianguzza, A.; Piazzese, D. Interactions of diethylenetriaminepentaacetic acid (dtpa) and triethylenetetraminehexaacetic acid (ttha) with major components of natural waters. Anal. Bioanal. Chem. 2003, 375 (7), 956-967.

(7) Martell, A. E.; Smith, R. M.; Motekaitis, R. J. NIST Standard Reference Database; NIST: Gaithersburg, MD, 2004; Vol. 46, p 8.

(8) Perrin, D. Stability Constants of Metal Ions Complexes, Part B: Organic Ligands, Chemical Data; Franklin Book Co.: Roswell, GA, 1979.

(9) Pettit, L.; Powell, K. J. The IUPAC Stability Constants Database; Academic Software: Otley, U.K., 2001.

(10) Kopylovich, M. N.; Baev, A. K. Combined hydrolysis of $\mathrm{Cu}^{2+}$ and $\mathrm{Ni}^{2+}$ salts in nitrate solutions. Zh. Neorg. Khim. 1996, 41 (10), $1751-1756$

(11) Kopylovich, M. N.; Evsei, E. A.; Baev, A. K.; Kirillov, A. M. Study of the $\mathrm{Fe}^{3+}-\mathrm{M}^{2+}-\mathrm{NO}_{3}{ }^{-}-\mathrm{H}_{2} \mathrm{O}$ system $\left(\mathrm{M}^{2+}=\mathrm{Co}^{2+}, \mathrm{Ni}^{2+}, \mathrm{Cu}^{2+}\right.$, $\mathrm{Zn}^{2+}$ ) with alkalization of the solution. Zh. Prikl. Khim. 2000, 73 (7), $1137-1140$.

(12) Kopylovich, M. N.; Iponova, N. A.; Baev, A. K.; Kirillov, A. M. Physicochemical parameters of cohydrolysis of $\mathrm{Fe}^{3+}$ and $\mathrm{M}^{2+}$ ions $\left(\mathrm{M}^{2+}\right.$ $=\mathrm{Co}^{2+}, \mathrm{Ni}^{2+}, \mathrm{Cu}^{2+}$, or $\mathrm{Zn}^{2+}$ ). Zh. Fiz. Khim. 2000, 74 (8), 1409-1411.

(13) Kopylovich, M. N.; Kirillov, A. M.; Baev, A. K. Equilibrium constants of the joint hydrolysis of alluminum (III) and divalent transition metal ions. Vestsi Nats. Akad. Navuk Belarusi, Ser. Khim. Navuk 2000, 2, 5-8.

(14) Kopylovich, M. N.; Kirillov, A. M.; Baev, A. K.; Chernik, A. A. Hydroxo complexes in the $\mathrm{Al}^{3+}-\mathrm{Cu}^{2+}-\mathrm{NO}_{3}^{-}-\mathrm{H}_{2} \mathrm{O}$. Zh. Neorg. Khim. 2000, 45 (5), 888-891.

(15) Kopylovich, M. N.; Radion, E. V.; Baev, A. K. Distribution of different forms of aluminium(III) and copper (II) in solutions and a scheme for the process of etheropolynuclear hydroxo complexation. Russ. J. Coord. Chem. 1995, 21 (1), 61-6.

(16) Purkevich, V. R.; Teluschenko, E. A.; Kopylovich, M. N.; Baev, A. K. Influence of hydroxo complexes of copper(II) and scandium(III) on their co-hydrolysis. Vestsi Nats. Akad. Navuk Belarusi, Ser. Khim. Navuk 2002, 1, 5-9.

(17) Radion, E. V. Simultaneous hydrolysis of copper(II) and cobalt(II) in nitrate solutions. Vestsi Nats. Akad. Navuk Belarusi, Ser. Khim. Navuk 1996, 2, 8-13.

(18) Sokolovskaya, D. M.; Radion, E. V.; Baev, A. K. Hydroxyl complex formation in $\mathrm{Cr}(\mathrm{III})-\mathrm{Cu}(\mathrm{II})-\mathrm{NO}_{3}^{-} \mathrm{H}_{2} \mathrm{O}$ system. Vestsi Nats. Akad. Navuk Belarusi, Ser. Khim. Navuk 1995, 3, 8-12.

(19) Yusov, A. B.; Budantseva, N. A.; Fedoseev, A. M.; Astafurova, L. N. Interaction of Aluminium(III) with Uranyl Ions in the Course of Joint Hydrolysis. Russ. J. Coord. Chem. 2001, 27 (11), 776-782.

(20) Yusov, A. B.; Fedoseev, A. M.; Astafurova, L. N. Interaction of Aluminium(III) with the f-Family Ions $\mathrm{Np}(\mathrm{VI}), \mathrm{Pu}(\mathrm{VI}), \mathrm{Np}(\mathrm{V})$, $\mathrm{Np}(\mathrm{IV}), \mathrm{Pu}(\mathrm{IV}), \mathrm{Nd}(\mathrm{III})$, and $\mathrm{Am}(\mathrm{III})$ in the Course of Simultaneous Hydrolysis. Russ. J. Coord. Chem. 2002, 28 (4), 264-271.

(21) Cigala, R. M.; Crea, F.; De Stefano, C.; Sammartano, S. Mixing effects on the protonation of polycarboxylates. Protonation of Benzenehexacarboxylate in $\mathrm{LiCl}-\mathrm{KCl}, \mathrm{NaCl}-\mathrm{KCl}, \mathrm{NaCl}-\mathrm{LiCl}$ and
LiCl-CsCl aqueous solutions at $I=1 \mathrm{~mol} \mathrm{~L}^{-1}$ and $T=298.15 \mathrm{~K} . J$. Chem. Eng. Data 2009, 54, 2137-2139.

(22) Cigala, R. M.; Crea, F.; Sammartano, S. Mixing effects on the protonation of polyacrylate in $\mathrm{LiCl} / \mathrm{KCl}$ aqueous solutions at different ionic strengths, $\mathrm{I}=1$ to $3.5 \mathrm{~mol} \mathrm{~L}^{-1}$, at $\mathrm{T}=298.15 \mathrm{~K}$. J. Mol. Liq. 2008, 143, 129-133.

(23) Crea, F.; Crea, P.; De Stefano, C.; Milea, D.; Sammartano, S. Speciation of phytate ion in aqueous solution. Protonation in $\mathrm{CsCl}_{\mathrm{aq}}$ at different ionic strengths and mixing effects in $\mathrm{LiCl}_{\mathrm{aq}}+\mathrm{CsCl}_{\mathrm{aq}}$ J. Mol. Liq. 2008, 138, 76-83.

(24) Crea, F.; Milea, D.; Sammartano, S. Enhancement of hydrolysis through the formation of mixed hetero-metal species. Talanta 2005, $65,229-238$.

(25) Crea, F.; Milea, D.; Sammartano, S. Enhancement of hydrolysis through the formation of mixed hetero-metal species: dioxouranium(VI)-cadmium(II) mixtures. Ann. Chim. (Rome) 2005, 95, 767-778.

(26) Baes, C. F.; Mesmer, R. E. The Hydrolysis of Cations; Wiley: New York, 1976.

(27) Brown, P. L.; Sylva, R. N.; Batley, G. E.; Ellis, J. The hydrolysis of metal ions. Part 8. Aluminum(III). J. Chem. Soc., Dalton Trans. 1985, $1967-1970$

(28) Cigala, R. M.; De Stefano, C.; Giacalone, A.; Gianguzza, A. Speciation of $\mathrm{Al}^{3+}$ in fairly concentrated solutions $(20-200 \mathrm{mmol}$ $\left.\mathrm{L}^{-1}\right)$ at $\mathrm{I}=1 \mathrm{~mol} \mathrm{~L}^{-1}\left(\mathrm{NaNO}_{3}\right)$, in the acidic $\mathrm{pH}$ range, at different temperatures. Chem. Spec. Bioavail. 2011, 23 (11), 33-37.

(29) Daniele, P. G.; Rigano, C.; Sammartano, S.; Zelano, V. Ionic Strength Dependence of Formation Constants. XVIII. The Hydrolysis of Iron(III) in Aqueous $\mathrm{KNO}_{3}$ Solutions. Talanta 1994, 41, 15771582.

(30) Cigala, R. M.; De Stefano, C.; Giacalone, A.; Gianguzza, A.; Sammartano, S. Hydrolysis of Monomethyl-, Dimethyl-, and Trimethyltin(IV) Cations in Fairly Concentrated Aqueous Solutions at $\mathrm{I}=1 \mathrm{~mol} \mathrm{~L}^{-1}\left(\mathrm{NaNO}_{3}\right)$ and $\mathrm{T}=298.15 \mathrm{~K}$. Evidences for the Predominance of Polynuclear Species. J. Chem. Eng. Data 2011, 56, $1108-1115$.

(31) De Stefano, C.; Princi, P.; Rigano, C.; Sammartano, S. Computer Analysis of Equilibrium Data in Solution. ESAB2M: An Improved Version of the ESAB Program. Ann. Chim. (Rome) 1987, 77, 643-675.

(32) De Stefano, C.; Mineo, P.; Rigano, C.; Sammartano, S. Ionic Strength Dependence of Formation Constants. XVII. The Calculation of Equilibrium Concentrations and Formation Constants. Ann. Chim. (Rome) 1993, 83, 243-277.

(33) De Stefano, C.; Foti, C.; Giuffrè, O.; Mineo, P.; Rigano, C.; Sammartano, S. Binding of Tripolyphosphate by Aliphatic Amines: Formation, Stability and Calculation Problems. Ann. Chim. (Rome) 1996, 86, 257-280.

(34) Daniele, P. G.; Foti, C.; Gianguzza, A.; Prenesti, E.; Sammartano, S. Weak alkali and alkaline earth metal complexes of low molecular weight ligands in aqueous solution. Coord. Chem. Rev. 2008, 252, 1093-1107.

(35) Vacca, A.; Sabatini, A.; Gristina, M. A. Two Problems Involved in Solving Complex Formation Equilibria: The Selection of Species and the Calculation of Stability Constants. Coord. Chem. Rev. 1972, 8, $45-53$. 